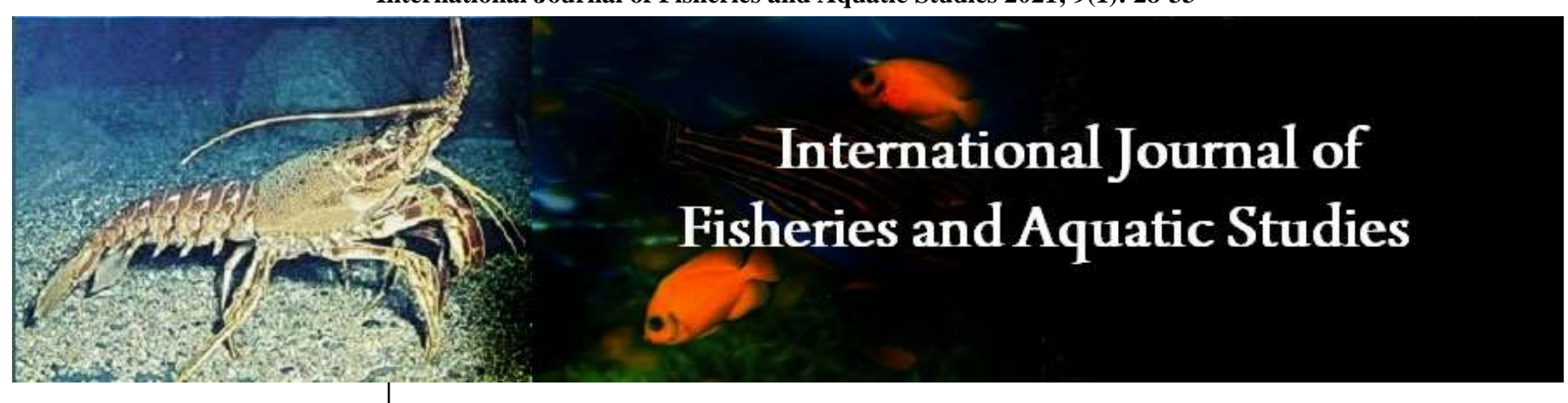

E-ISSN: 2347-5129

P-ISSN: 2394-0506

(ICV-Poland) Impact Value: 5.62

(GIF) Impact Factor: 0.549

IJFAS 2021; 9(1): 28-33

(C) 2021 IJFAS

www.fisheriesjournal.com

Received: 06-11-2020

Accepted: 13-12-2020

\section{Birol Baki}

Department of Aquaculture,

Sinop University, Faculty of

Fisheries, Sinop, Turkey
Corresponding Author: Birol Baki

Department of Aquaculture, Sinop University, Faculty of Fisheries, Sinop, Turkey

\section{Capacity utılızation in aquaculture in Turkey}

\section{Birol Baki}

DOI: $\underline{\text { https://doi.org/10.22271/fish.2021.v9.i1a.2384 }}$

\begin{abstract}
In the study, production and capacity utilization rates and annual production of farms engaged in aquaculture in Turkey are determined. Turkey aquaculture production has reached 373356 tons in 2019. Of this production, $68.82 \%$ was produced in marine aquaculture and $31.18 \%$ was produced in the inland aquaculture. In Turkey, in 2019, $79.6 \%$ of the farms actively engaged in production was in inland and $20.4 \%$ was in the seas. It has been evaluated that $29.15 \%$ of the farms where $65.83 \%$ of the total fishery product needs are met in the Aegean Region. In aquaculture in Turkey, the total project capacity was determined to be 522778 tons. As is the case in production level and the number of farms, the highest capacity is 245894 tons in the Aegean Region, followed by the Black Sea Region with 75611 tons and Eastern Anatolia Region with 62349 tons. The project capacity utilization rates of the enterprises were $84.45 \%$ in the seas and $53.77 \%$ in inland, and it was determined as $71.42 \%$ in general.
\end{abstract}

Keywords: Number of farms, aquaculture production, project capacity, project capacity utilization

\section{Introduction}

Marine aquaculture of fish has become more intensive over the last 15 years due mainly to the introduction of new technologies, the expansion of suitable sites, improvements in feed technology, improved understanding of the biology of the farmed species, increased water quality within farming systems and the increased demand for fish products (De Voe, 1994; Ross, 1997) ${ }^{[1,2]}$. Seafood is an important source of protein, the global demand for which has risen remarkably in recent decades (FAO, 2016) ${ }^{[3]}$. Parallel to rising demand, especially since the 1950s onwards, industrial fishing expanded step by step-horizontally, from coastal waters to open seas; vertically, from shallow waters to deep seas; and taxonomically, from bigger species to smaller ones; in other words, by "fishing down marine food webs" at lower trophic levels (Pauly et al., 1998) ${ }^{[4]}$.

Studies are carried out on aquaculture production and capacity utilization in different countries of the world (FAO, 2003; Agbelege and Olarewaju, 2010; Hagar Dighiesh, 2014; Adewumi, 2015; Kaunda and Chimatiro, 2015; Wally, 2016; Jerimoth et al., 2017; Daramola et al., 2017; Jega et al., 2018; Icon et al., 2020; Kaleem and Sabi, 2020) ${ }^{[5,6,7,8,9,10,11,12,13,14,15] .}$

In Turkey, a large part of the water resources is used in drinking, irrigation, industrial and energy fields. In addition, due to the low water quality criteria, unsuitable land structure, nature events, etc., the use of water in the aquaculture sector is limited. Although the limited usable areas substantially affect the aquaculture activities that are carried out in these areas, technological facilities significantly contribute to increase in the production.

\section{Aquaculture production in Turkey}

Aquaculture has started in 1970 with inland aquaculture and has started to expand in the mid1980s with marine aquaculture and is still in growth every year thanks to the technological developments. Today, trout and carp aquaculture are conducted in the freshwaters whereas aquaculture for trout, sea bass, sea bream, tuna fish, mussels and some alternative species are carried out in the Turkish seas. The production of aquatic products, which was 3075 tons in 1986 and 79031 tons in 2000, became 373356 tons in 2019 (Fig 1, Fig 2) (TUIK, 2020) ${ }^{16}$. Aquaculture production has especially increased since 2002. 


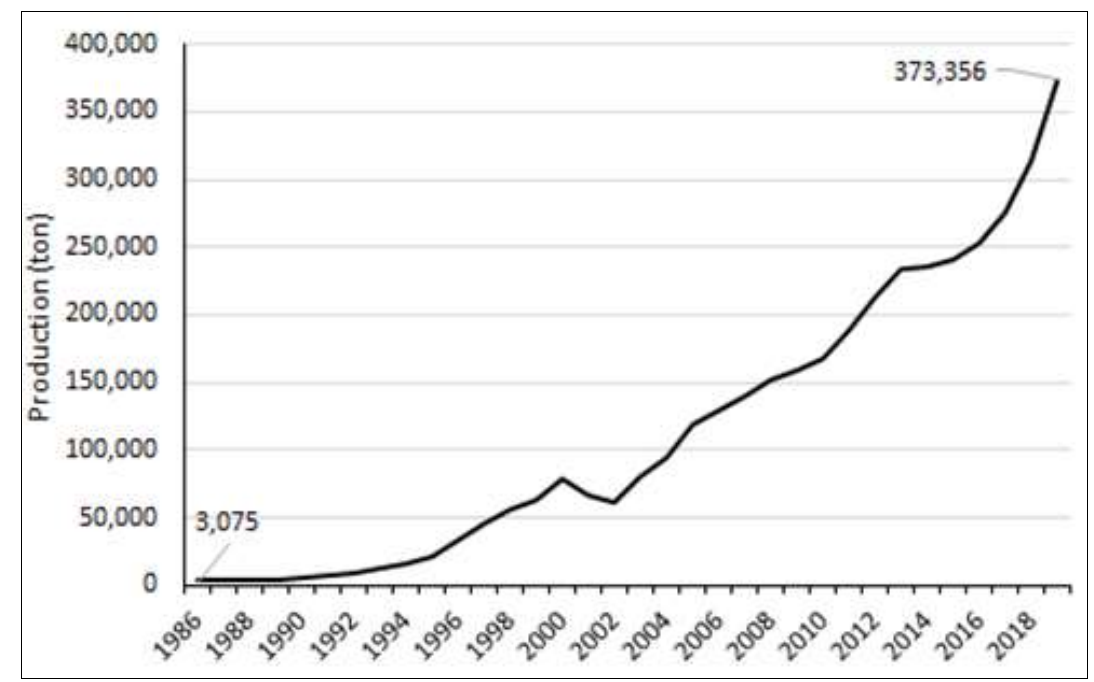

Fig 1: Aquaculture production in Turkey

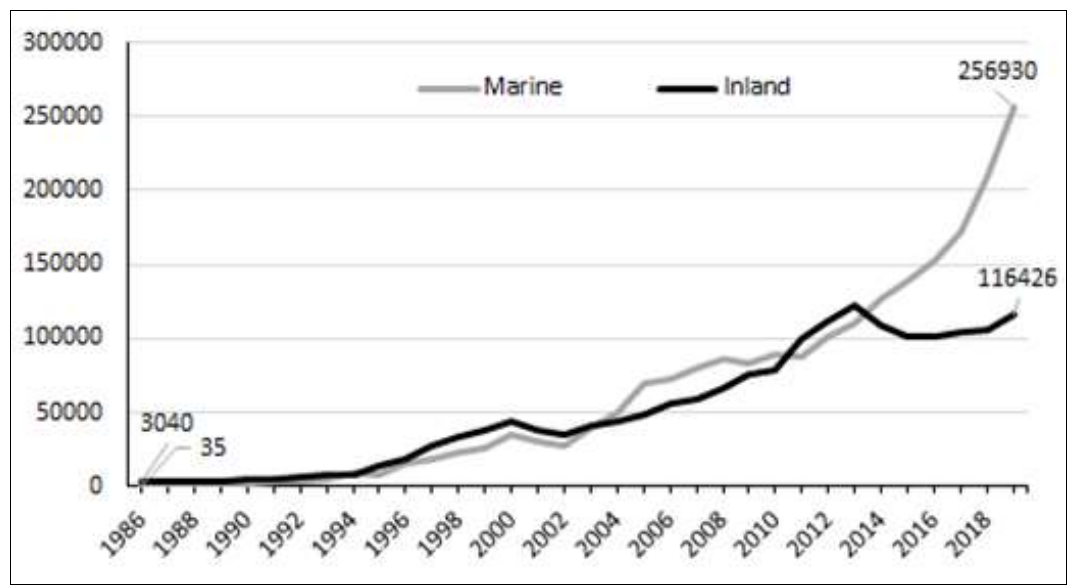

Fig 2: Aquaculture production in the seas and inland in Turkey

Examining the production chart, especially after 2002, aquaculture production in the sea and in the inland has increased. The production in the seas was 35646 in the year 2000 while it increased to 256930 tons in 2019. The production in the inland reached from 43385 in 2000 to 116426 tons in 2019.
Examining the ratio of aquaculture production, it is determined that the production rate of marine fish production is $45.1 \%$ and inland aquaculture production is $54.9 \%$ in 2000 , while the production rate of marine fish production is $68.82 \%$ and inland aquaculture production is $31.18 \%$ in 2019 (Fig 3).

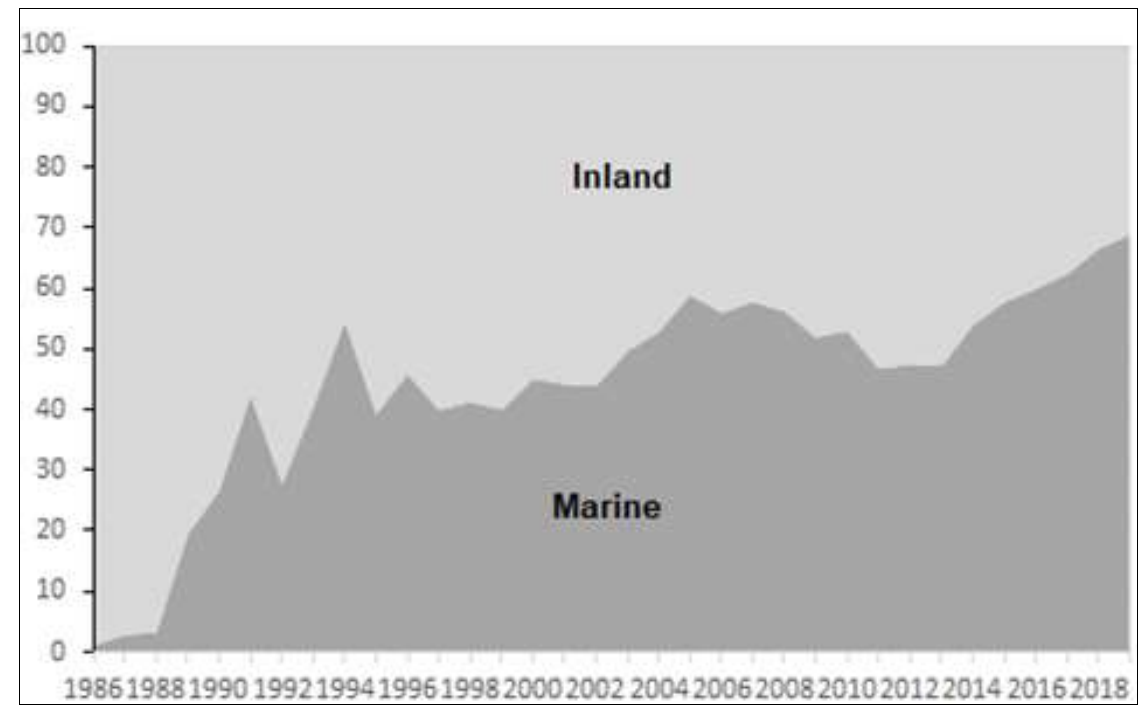

Fig 3: Marine and inland aquaculture production ratios

Turkey has a coastline exceeding $8300 \mathrm{~km}$, extending along the Black Sea coast (20.4\%), the Sea of Marmara (17.3\%), the
Aegean (41.8\%), and the Mediterranean (20.5\%) (UNEP, 2005) ${ }^{[17]}$. 
Examining the production levels according to the regions, in 2019, the highest production was carried out in the Aegean Region with 245794 tons whereas the lowest production was in the Eastern Anatolia Region with 6414 tons. In terms of the production ratios, $65.83 \%$ of the aquaculture production was carried out in the Aegean Region, 9.92\% in the Southeastern Anatolia Region, $8.95 \%$ in the Mediterrean Region, $8.29 \%$ in the Black Sea Region, 2.64\% in the Marmara Region, 2.64\% in the Central Anatolia Region and $1.72 \%$ in the Eastern Anatolia Region (Fig 4).

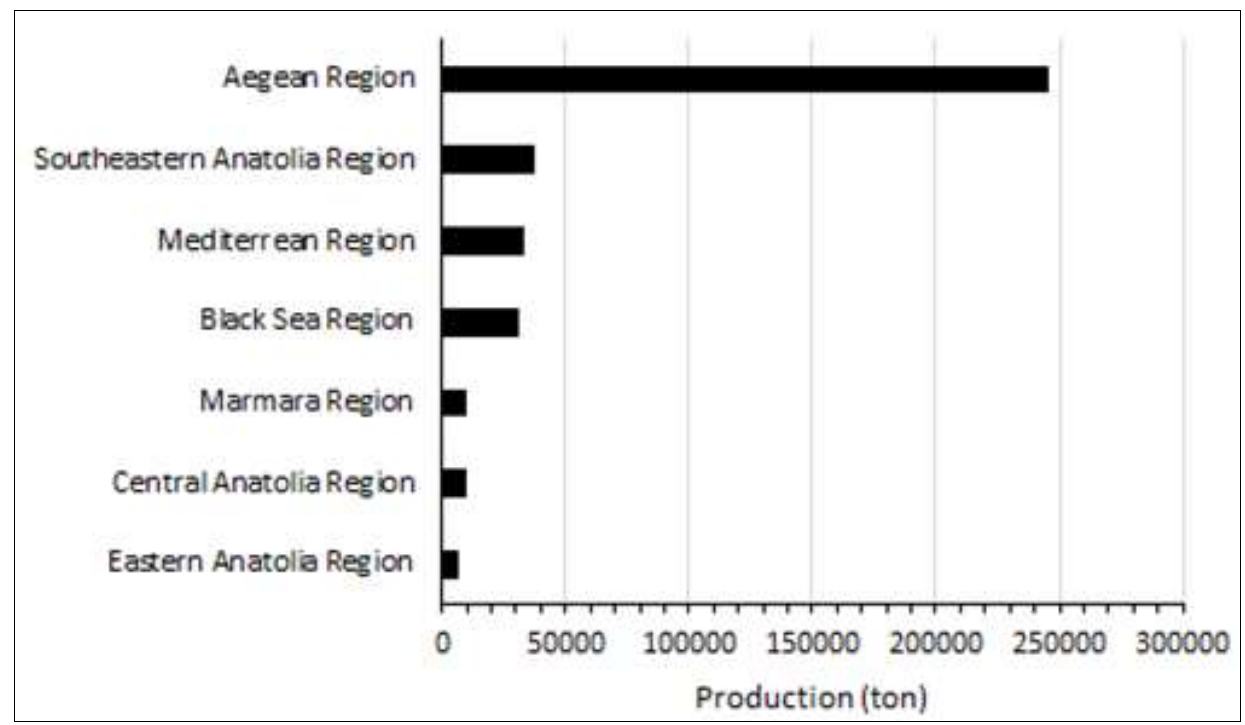

Fig 4: Production levels according to the regions

Marine aquaculture production depends principally on coastal cage farming in Turkey, as only a small amount is produced in land-based systems. Of cage farms, $92 \%$ are located in the Aegean region, where geographical and hydrographical conditions are suitable for the cultivated species (Yucel-Gier et al., 2009) ${ }^{[18]}$.

Examining the number of farms according to years, it was determined that the number of marine aquaculture farms was 420 in 2014 and increased to 434 in 2019 while the number of inland aquaculture farms was 1945 in 2014 and decreased to 1693 in 2019. It was found that the total number of farms decreased in the same years (2365 in 2014, 2127 in 2019). In $2019,79.60 \%$ of actively running farms in Turkey were in inland and $20.40 \%$ in the seas (Fig 5).

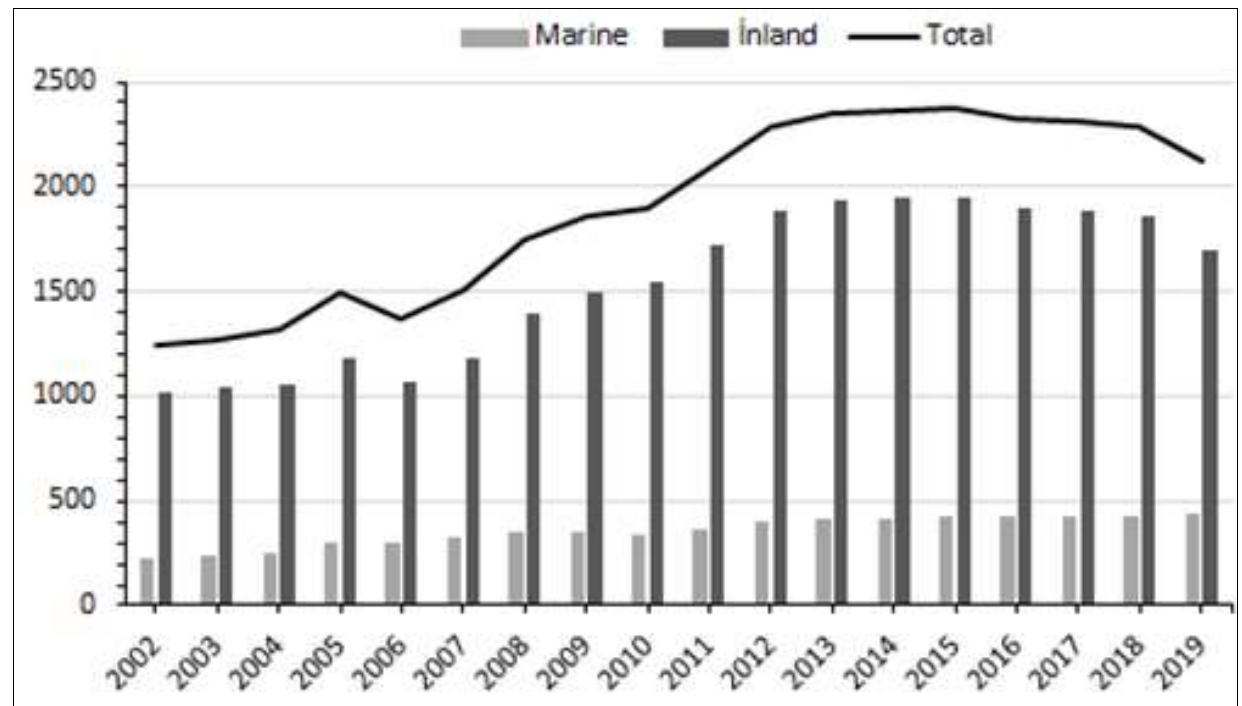

Fig 5: The number of aquaculture farms

Examining the distribution of farms among the regions, the highest number of farms are in the Aegean Region with 620 farms whereas the lowest number of farms were in the in the Southeastern Anatolia Region with 76 farms. Accordingly, $29.15 \%$ of the aquaculture farms are located in in the Aegean Region, $20.36 \%$ in the Black Sea Region, $17.07 \%$ in the Mediterranean Region, $16.36 \%$ in the Eastern Anatolia
Region, $7.71 \%$ in the Central Anatolia Region, 5.78\% in the Marmara Region, and $3.57 \%$ in the Southeastern Anatolia Region. In terms of marine farms, $81.11 \%$ of the farms in the Aegean Region, $9.45 \%$ of the farms in the Black Sea Region, $6.22 \%$ of the farms in the Mediterranean Region and $3.23 \%$ of the farms in the Marmara Region, and are facilitated at the seas (Fig 6). 


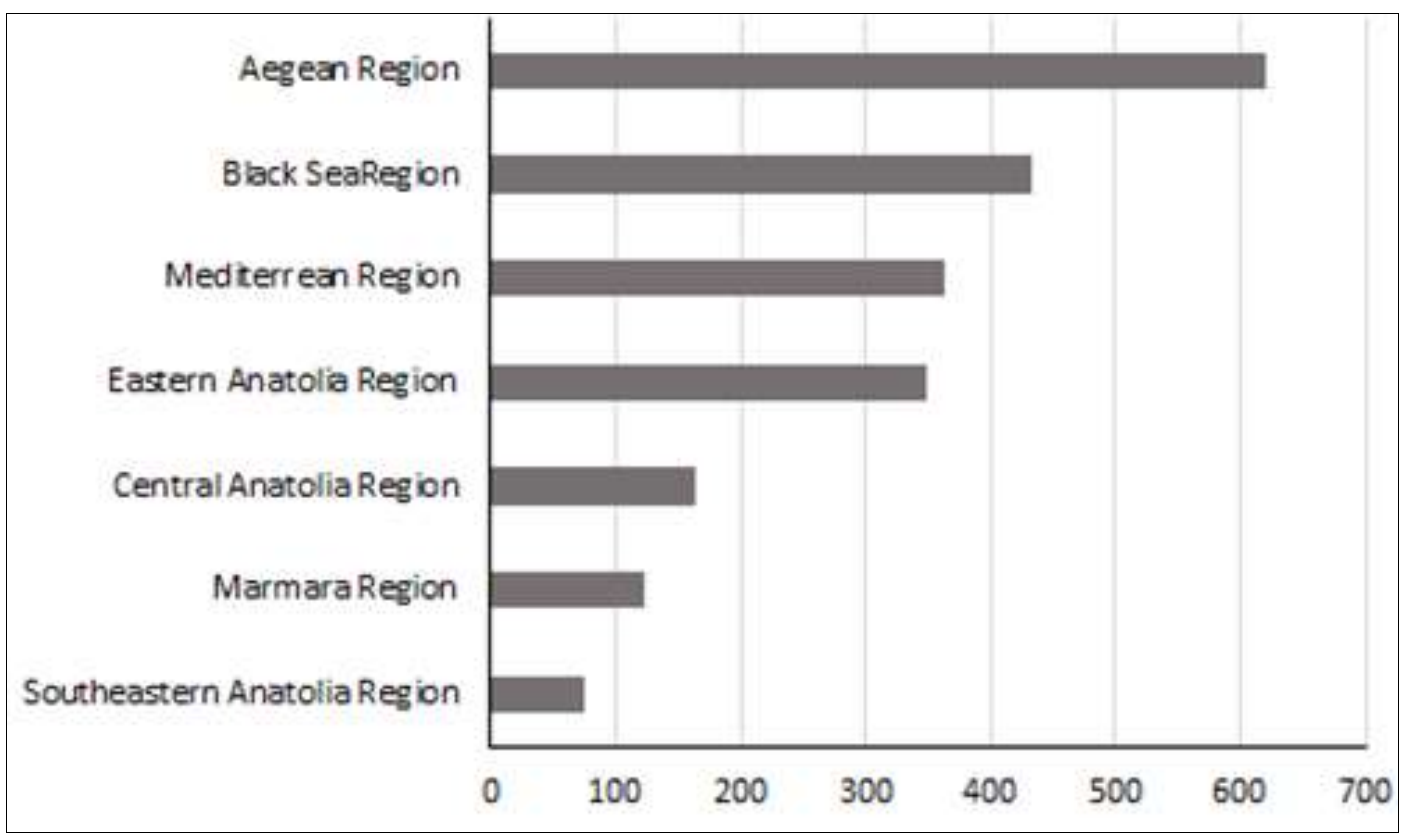

Fig 6: The number of farms according to the regions

Examining the farms capacities, it was seen that the number of farms operating at the seas do not increase substantially (420 in 2014; 434 in 2019), and the farms capacities reached from 223674 tons to 304232 in 2019 . Parallel to the decrease in the number of farms in the inland, the farm capacities decreased from 248455 tons in 2014 to 216548 tons in 2019. The total capacity increased to 522778 tons in 2019 (Fig 7).

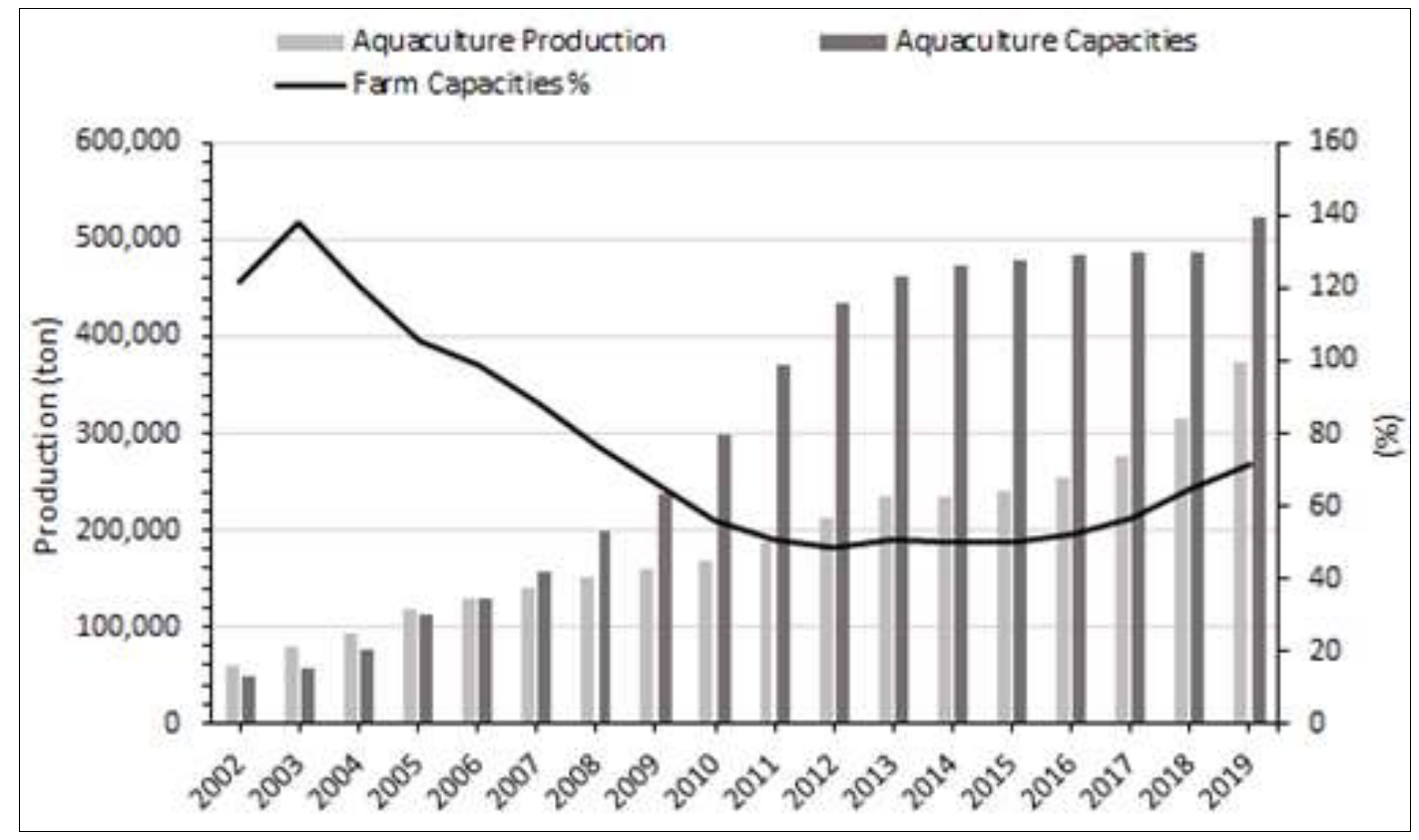

Fig 7: Farm capacities according to the regions

Examining the farm capacities according to the regions, the highest capacity is in the Aegean Region with 245894 tons whereas the lowest capacity is in the Southeastern Anatolia Region with 22840 tons. In terms of the regional ratios, $47.04 \%$ of the total capacity of aquaculture production is in the Aegean Region, $14.46 \%$ in the Black Sea Region, $11.17 \%$ in the Mediterranean Region, $11.93 \%$ in the Eastern Anatolia Region, $6.66 \%$ in the Central Anatolia Region, $4.38 \%$ in the Marmara Region and $4.37 \%$ in the Southeastern Anatolia Region (Fig 8). 


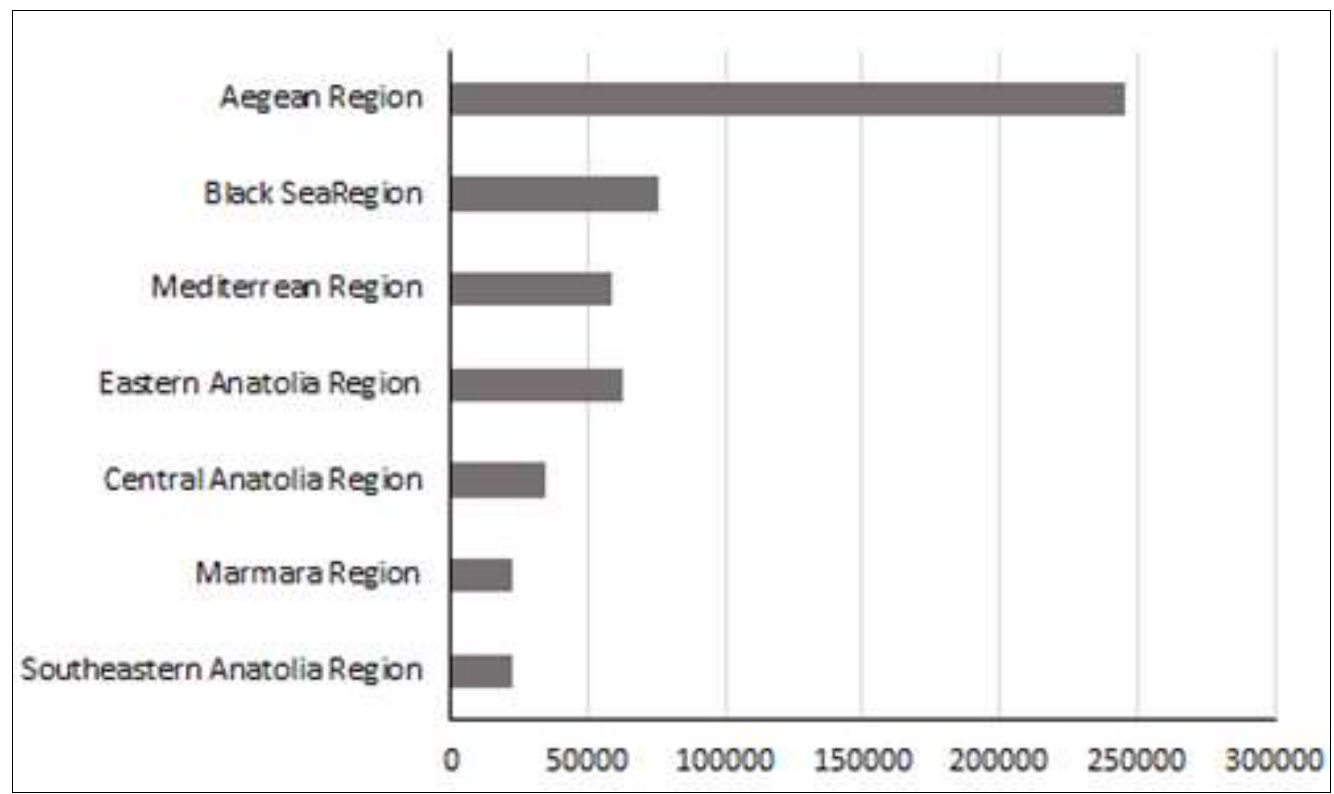

Fig 8: Farm capacities according to the regions

Examining the capacities, production amount and capacity utilization rates of the farms, it was determined that the 99.96\% capacity was used in the Aegean Region which has the highest operational capacity and production capacity (Fig 9).

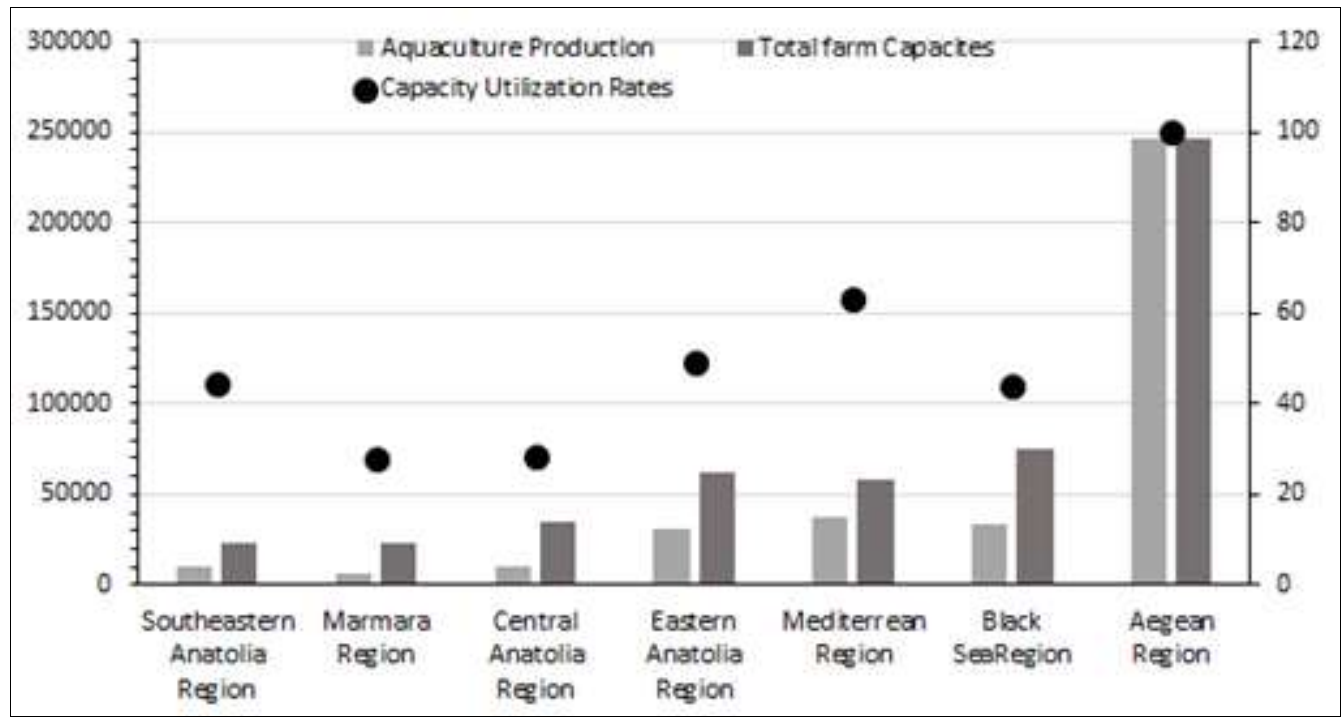

Fig 9: The operating capacity of the regions, the amount of production and capacity utilization rates

The other regions were found to have capacity utilization rates of $63.26 \%$ in the Mediterranean Region, $49.33 \%$ in the Eastern Anatolia Region, $44.53 \%$ in the Southeastern Anatolia Region, $44.21 \%$ in the Black Sea Region, $28.32 \%$ in the Central Anatolia Region and $28.03 \%$ in the Marmara Region. The capacity utilization rate of aquaculture farms was calculated as $84.45 \%$ for the seas and $53.77 \%$ for inland, and as $71.42 \%$ for all farms.

\section{Conclusion}

The aquaculture industry, which accounts for over 50 percent of global fish production, is the fastest-growing foodproducing sector. About 424 aquatic species are cultivated globally, benefiting millions through the provision of nutrition, food security and sustainable livelihood, and poverty reduction (Galappaththi et al., 2020) ${ }^{[19]}$. Over the past two decades, world aquaculture has developed tremendously to become an economically significant industry.
The industry continues to grow at an average global annual growth level of 8.8 percent per year compared with all other animal food production industries (Onada and Ogunola, 2017) ${ }^{[20]}$. As a result, it is seen that the realization rate of production capacities of the projects in Turkey is approximately $71.42 \%$. The most important reason for the failure in the transformation of capacity $(\% 100)$ to production is the economic issues that the farmers encounter.

Konstantinidis et al. (2020) [21], marine fish farming in northern Ionian Sea and southern Adriatic represent significant production centers with potential for further horizontal, vertical, and taxonomic expansion. This expansion is necessary to fulfil current demand (i.e. market growth), as trading and consumption of sea bass and sea bream have increased in the EU in recent years by $5-6 \%$ in annual base (EUMOFA 2017) ${ }^{[22]}$. Within this context, the current work is not only an insight to certain production aspects of the sector in Greece and Albania but also aims to provide a credible tool 
to assist the acquisition of production capacity data and even management on farm and sectoral level in the Mediterranean Sea.

Also, in addition to the farms established for growing fish, there are also difficulties in supplying the necessary materials for production such as fish, feed, cage, pool as well as planned enterprises for growth. Furthermore, the lack of a detailed examination of the environmental, production, and economic feasibility of the production area is a barrier to the production turnaround of project capacities. Capacity utilization (\%100) rates of farms will increase with the knowledge of the biological characteristics and environmental requirements to be cultivated in the project area, the control of all the factors that affect the water, the employment of the fishery engineers and determination of the marketing policy.

\section{References}

1. DeVoe MR, Aquaculture and the marine environment: policy and management issues and opportunities in the United States Bull. Natl. Res. Inst. Aquacult. Supp 1994;1:111-123.

2. Ross A. Leaping in the Dark: A Review of the Environmental Impacts of Marine Salmon Farming in Scotland and Proposals for Change Scottish Environment Link, Perth, Scotland 1997, 92.

3. FAO, The State of World Fisheries and Aquaculture: Contributing to food security and nutrition for all. Rome. 2016. http://www.fao.org/3/a-i5555e.pdf.

4. Pauly D, Christensen V, Dalsgaards J, Froese R, Torres F $\mathrm{Jr}$, Fishing down marine food webs. Science 1998;279:860-863.

5. FAO, Egypt national aquaculture sector overview: Characteristics, structure and resources of the sector Fisheries and Aquaculture Department, 2013. http://www.fao.org (Access date: 18 September 2020).

6. Agbelege OO, Olarewaju AN, Prospects and problems of aquaculture in Borno State, Nigeria. In: 25th Annual Conference of the Fisheries Society of Nigeria (FISON), Lagos, Nigeria 2010, 94-97.

7. Hagar Dighiesh HS, Brief summary about aquaculture in Egypt, J Aquac. Mar. Biol 2014;1(1):3. 10.15406/jamb.2014.01.00003.

8. Adewumi AA. Aquaculture in Nigeria: Sustainability issues and challenges, Direct Resource Journal of Agriculture and Food Science 2015;3:12.

9. Kaunda E, Chimatiro S, Study on the potential of aquaculture in Africa 2015, 39.

10. Wally A. The state and development of aquaculture in Egypt, Glob. Agric. Inf. Netw 2016, 1-14.

11. Jerimoth E, Irabor K, Ebuka A, A review of aquaculture production in Nigeria: Problems and prospects, Journal of Northeast Agricultural University English Edition, 2017;3:11.

12. Daramola JJA, Osofero SA, Kester CT, Gbadamosi OK. Overview of status of aquaculture in Nigeria with reference to Ekiti state Agricultural Journal 2017;2(3):447-452.

13. Jega IS, Haque MM, Miah MI, Analogical viewpoint of fisheries and aquaculture between Bangladesh and Nigeria: Potential of knowledge transferability, Journal of the Bangladesh Agricultural University 2018;16(3):523532. 10.3329/jbau.v16i3.39450.

14. Icon EK, Icon CP, Batzios C, Michaelidis B, Ganias K. Estimating cage farming capacity of data-poor mariculture sectors in the Eastern Mediterranean, Journal of Applied Aquaculture 2020. https://doi.org/10.1080/10454438.2020.1721395.

15. Kaleem O, Sabi ABS. Overview of aquaculture systems in Egypt and Nigeria, prospects, potentials, and constraint, Aquaculture and Fisheries 2020, in press, https://doi.org/10.1016/j.aaf.2020.07.017.

16. TUIK. Fishery Statistics. Turkish Statistical Institute, Ankara, $\quad 2019 . \quad$ turkey, gov.tr/medas $/ \mathrm{kn}=97 \&$ locale $=\operatorname{tr} \quad$ (Access date: 20 September 2020).

17. UNEP. Coastal Area Management in Turkey, Priority Actions Programme Regional Activity Centre, Split, 2005.

18. Yucel-Gier G, Uslu O, Kucuksezgin F, Regulating and monitoring marine finfish aquaculture in Turkey. J Appl. Ichthyol 2009;25:686-694.

19. Galappaththi EK, Aubrac CJ, Ichien ST, Hyman AA, Ford JD, Climate change adaptation in aquaculture, Reviews in Aquaculture 2020,1-17. 10.1111/raq.12427.

20. Onada OA, Ogunola OS. Effects of catfish (Clarias gariepinus) brood-stocks egg combination on hatchability and survival of fish larvae, Journal of Aquaculture Research \& Development 2017, 2. https://doi.org/10.4172/2155-9546.s2-014.

21. Konstantinidis E, Perdikaris C, Gouva E, Nathanalides C, Bartzanas T, Anestis V et al. Assessing Environmental Impacts of Sea Bass Cage Farms in Greece and Albania Using Life Cycle Assessment. Int. J. Environ. Res. 2020;14:693-704. https://doi.org/10.1007/s41742-02000289-8.

22. EUMOFA (European Market Observatory for Fisheries and Aquaculture Products), The EU fish market. 108 pp. Brussels, Belgium: European Commission, Directorate General for Maritime Affairs and Fisheries, DirectorGeneral, 2017. 